\title{
QUALITY INNOVATION IS IMPERATIVE FOR THE NEW, SUSTAINABLE QUALITY (OF LIFE!)
}

\author{
INOVACIJA KVALITETE IMPERATIV JE ZA NOVU, \\ ODRŽIVU KVALITETU (ŽIVOTA!)
}

\author{
Mila Božič \\ BE-i Institute, Slovenia/Slovenia \\ E-mail: mila.bozic@be-i.org \\ Andrej Trebar \\ Creative Plus, Slovenia/Slovenia \\ E-mail: andrej.trebar@siol.net
}

UDK/UDC: 001.895:608.32:502/504

JEL klasifikacija/JEL classification: L15; Q56

DOI: $10.30657 / \mathrm{hdmk} .2020 .02$

Pregledni članak/Review

Jezik/Language: Engleski/English

"In times of turbulence, the biggest danger is not the turbulence itself but to act with yesterday's logic" (Peter Drucker).

\begin{abstract}
Ecological collapse and climate disaster threaten everything. Social media is driving us crazy. We are taking giant steps to build ecological awareness and a new sustainable quality of life. In our roles as $Q M-Q P s$ (quality managers-quality professionals), we are responsible for providing expertise in all dimensions of QMS (quality management systems) (planning, assurance, control, and improvement). The knowledge of standards, models, and other regulations as well as tools and techniques for measurements and improvements are obvious parts of our services. There are many reasons to scale $Q P$ engagement from a basic desire to be more $Q$-quality centric, by informing the creation of new $Q$ services or enabling improved customer access to new, sustainable Q. The existing QMSs and their practices and models in organizations are no longer effective for the challenges, especially related to networked businesses and ecosystems. Are we professionally aware of the global state of quality?
\end{abstract}

Key words: quality innovation, systems thinking, personal reinvention, sustaining change.

\section{INTRODUCTION}

In the article we explain:

- How to overcome our stagnant role and internal barriers to change;

- How to rebuild our QMS internally: use insights and tools, TRIZ (Theory of Inventive Problem Solving) in specific to outline the right solutions as imperative for better services. 
It's not just the role of quality developers: when and how to engage Q, or approaches to gather a holistic view on how quality and QMS programs can best operate. How to lead change and influence people is more important for all types of professionals, including QPs, than ever in the past. To adapt and innovate continuously we need first to reinvent ourselves and our organizations to build capability for the challenges of a new pace of change. This personal reinvention is more demanding in the sense of psychology than technical expertise. It requires emotional intelligence and mental stability to evolve from "ego" to "eco" and intuitive leadership behavior and approaches. Having experience in leading QMS and IMS (integrated management aystem) (new ISO 56000 for sustainable innovation), quality professionals and leaders are able to facilitate and perform such a balanced integration of both standards in our organizations, support systemic innovation management, and be the change catalyst in delivering a company's vision and new, sustainable quality.

To all professionals (QPs) and leaders who are serious about initiating and sustaining positive change for themselves, their organizations, and our planet it is obvious that we have to master and integrate the domains of systems thinking, personal mastery, and teamwork, as they influence and enable sustainable development of the whole.

\section{NEW Q EXPERTISE NECESSARY}

The findings of the first ICQEM global state of quality study ${ }^{1}$ allow the identification of different quality profile groups, and each one reflects similar behaviors that the countries of the same group perform. Five groups were created: Leading; Follower; Moderate; Lagging; and Beginning. A model encompassing 10 dimensions and 16 indicators was developed to cover the macro-quality approach to understanding how each country is performing. Most countries from our region of central and eastern Europe scored among Followers and Moderates (for example, Czech Republic: 13, Slovenia: 17, Hungary: 26, Slovakia: 27, Poland: 28, Croatia: 29, Serbia: 38, etc.). Taking into account that these countries rank much lower on the World Competitiveness Index ${ }^{2}$, it can be seen that in many aspects our Q performance has enormous room for improvement, even without taking into account the urgent call for sustainable, ecological, and socially balanced quality worldwide. ${ }^{3}$

Facing virtual reality and the complexity of environmental changes we are more and more aware that we have to reconsider our QP role, responsibility, and changes needed to enable sustainable quality for a more reliable future.

Quality guru William Edwards Deming stressed repeatedly that leaders must not necessarily have the depth of understanding of these individual bodies of knowledge: systems theory, theory of variation, psychology and theory of knowledge; rather, they should have a good grasp of how the interdependence of these elements affect the quality and capability of the organization.

These four pillars, along with the 14 points that Deming illustrated in his book Out of the Crisis, represent a guideline for a cultural and Q transformation towards system change and systems quality management, which is still a weak point in our professional expertise and practice. Again, we can be inspired by Deming saying that an organization is "a network of

\footnotetext{
${ }^{1}$ Proceedings of the $3^{\text {rd }}$ ICQEM Conference, Barcelona, Spain, 2018, pp. 473.

${ }^{2}$ https://www.weforum.org/rep HYPERLINK "https://www.weforum.org/reports/how-to-end-a-decade-of-lostproductivity-growth"o HYPERLINK "https://www.weforum.org/rep HYPERLINK

"https://www.weforum.org/reports/how-to-end-a-decade-of-lost-productivity-growth"orts/how-to-end-a-decadeof-lost-productivity-growth"rts/how-to-end-a-decade-of-lost-productivity-growth

${ }^{3}$ http://www3.weforum.org/docs/WEF_Sustainability_Strategy_2021.p HYPERLINK

"http://www3.weforum.org/docs/WEF_Sustainability_Strategy_2021.pdf"df
} 
interdependent components that share a common goal." In the language of network theory we can say that any organization can be portrayed as a "directed network;" that is, a network with a goal.

What do we mean when we say that any organization is a system and how can we connect such a system within QMS? This has been our prime task. We consider key definitions and points below. The what, why, who, and to whom we need to make us relevant for the new Q-reality to sustain itself. Focused attention plays a key role from task, issue, or problem identification toward proper solutions.

In most organizations with lagging $\mathrm{Q}$, we have to refocus more profoundly from symptoms to underlying causes. We have to be trained in systems thinking to regenerate natural systems and build a new social, homeostatic system. Following general trends:

- Less linear economy thinking, and more circular economy (3Rs: reuse, repair, recycle) and systems thinking!

- Move from prevailing serving the standards and models to use of the quality tools to create $\mathrm{Q}$ innovation;

- Learn how to bring and nurture the human element in all multidisciplinary tasks - coaching, raising awareness of the need for that sustainable Q imperative.

\section{SYSTEM THINKING APPLIED BY THE QP}

"A system may be defined as a set of elements standing in interrelation among themselves and with the environment. Thinking systematically ... is not the same as systems thinking. Systems thinking is about taking a holistic approach that views the team and its environment as interconnected and complex". ${ }^{4}$

Some additional perspectives on systems thinking definitions are as follows: ${ }^{5}$

- "Systems thinking requires the consciousness of the fact that we deal with models of our reality and not with the reality itself;" 6

- “...what is often called, ,systems thinking ... is ... a bundle of capabilities, and at the heart of it is the ability to apply our normal thought processes, our common sense, to the circumstances of a given situation;",

- "Systems thinking provides a powerful way of taking account of causal connections that are distant in time and space." 8

- Dynamics within the system are always dominated by the slowest components.

Chaos and complexity theories have also impacted the development of systems thinking, including the treatment of such concepts as emergence. According to Gharajedaghi, "Systems thinking is the art of simplifying complexity. It is about seeing through chaos, managing interdependency, and understanding choice. We see the world as increasingly more complex and chaotic because we use inadequate concepts to explain it. When we understand something, we no longer see it as chaotic or complex."

According to systems thinking, the whole emerges from the interactions among its parts. Parts are related through complex multiple influences. Thus, its defining characteristics do not

\footnotetext{
${ }^{4}$ https://www.sebokwiki.org/wiki/What_is_Systems_Thinking\%3F

${ }^{5}$ Ibid.

${ }^{6}$ Günther Ossimitz, The development of system thinking skills using system dynamics modelling tools, Klagenfurt, Universitat Klagenfurt, 1997.

${ }^{7}$ Dietrich Dörner, The logic of failure - Recognizing and avoiding error in complex situations, Perseus books, Cambridge, Massachusetts, 1996.

${ }^{8}$ Ralph D. Stacey, Douglas Griffin and Patricia Shaw, Complexity and Management: Fad or Radical Challenge to Systems Thinking? (Complexity and Emergence in Organizations), Routledge, London, 2000.
} 
exist in its parts. Importantly, the systems-thinking paradigm differs from the reductionist paradigm in terms of how parts interact or interrelate within the system. Just as reductionist scientists were of the opinion that everything could be reduced to indivisible parts, they also believed that relationships among parts were reducible to one simple relationship: that of cause and effect, emphasizing the relation between a first event (the cause) and a second event (the effect). According to systems thinking, the many interactions that transpire within each system cannot be reduced to a single cause-effect relationship. The first event is likely to contribute to the second event, but many additional events are also seen as contributing to that second event. Thus, all explanations for the second event should take into account the influence of multiple factors. Systems thinking thereby diverged from the predominant reductionist paradigm by upholding that the explanation for any phenomenon within a system cannot be too simplistic, and that the impact of the environment cannot be ignored.

Ludwig von Bertalanffy, an Austrian-born biologist (1901-1972), was one of the pioneers of systems thinking. It is not surprising that systems thinking evolved among biologists, because biology is concerned with the study of living organisms, which are actual living systems. The study of biology essentially comprises a study of systems, and so the encounter of systems thinking with biology was particularly fruitful. At one point in his work, von Bertalanffy resisted the reductionist paradigm as a panacea for investigating all scientific problems.

According to reductionist thinking, the whole can be broken down into its parts and put back together from its parts. Parts are related through a simple cause-effect relationship. Thus, its defining characteristics exist in its parts. In the modern era, that misleading approach of reductionism dominates Western thought, manifesting itself in all areas of Western knowledge and practice. Physicists, for example, stated that all physical objects could be broken down into indivisible particles of matter called atoms.

The systems thinker or QP-coach understands that change emerges from a broad pattern of exchange and dialogue with all stakeholders:

- Systems thinking is about taking a holistic approach that views the organization and its environment as interconnected and complex.

- Chaotic systems are: • Apparently disorderly and random • Actually ordered ... but the pattern is hard to discern ("strange attractor" - atypical pattern) - Stable instability or instable stability • Change happens at the "edge of chaos."

Watch yourself:

- First-order systems approach: • Focus on goal setting \& action planning • Exploring the self-regulation process $\bullet$ Noticing feedback to and from the wider system.

- Second-order systems - Focus on client's mental model - Focus on your mental model $\bullet$ Draw new representations of the system $\bullet$ Encourage interactions within the hypothetical system.

- Complexity $\cdot$ Engage in dialogue $\cdot$ Notice patterns of dialogue $\cdot$ Pay attention to power dynamics $\bullet$ Notice social identities $\bullet$ Encourage new thinking and adaptation, etc.

- Which order of systems thinking we apply approaches the cause-effect relation of the problem or task tries to address results in different beliefs and behaviors, and impact the level of the solution.

- First-order beliefs assume: • Organizational systems are real • You can break down the system into sub-components - Organizational systems function like other systems $\cdot$ Look hard enough and you will find A $>\mathrm{B}>\mathrm{C} \cdot$ Systems strive to equilibrium - You can stand outside a system and plot an intervention:

- Following first-order behaviors - Collect data in order to understand the organization, client or task $\bullet$ Focus on components of the system $\bullet$ Spend 
time motivating individuals $\bullet$ Ensure individual components have access to feedback • Build long-term plans.

- Second-order beliefs presume: - Organizational systems are real - You can break down the system into sub-components - Organizational systems are mysterious • One perspective isn't enough - All perceptions and observations are fallible • Learning through experience:

- Following second-order behaviors • Encouraging self-awareness • Exploring others' mental models $\bullet$ Holding hypotheses lightly $\bullet$ Open to others' interpretations of events • Expect the unexpected!

\section{CREATIVE AND INTUITIVE LEADERSHIP ENABLES SUSTAINABLE Q}

As we explored complexity theory we had set, Scharmer and Kaufer's ${ }^{9}$ work on "ego-" and "eco-" systems awareness offers a conceptual framework with which to approach leadership capabilities from a new angle. They point to a major disconnect and challenge facing leadership today, being how to bridge the gap between the eco-system reality and the egosystem mindset. They expanded this work on ego and eco mindsets and have added intuitive leadership as a third important capacity in leading complex organizations. The authors draw a direct parallel between organizational dynamics and natural eco-systems. Eco-systems are selforganizing and adaptive in that they do not have a central controlling agent (manager); and a change in one part causes a ripple effect throughout the whole eco-system. This is mirrored in complex organizations.

For example, informal leaders continuously influence the behavior and attitudes of others in their local areas, who in turn influence others, and thus behaviors are changed throughout the organizational eco-system, often including suppliers and customers.

Through our work in organizations and our study of the literature, it became clear that thriving organizational eco-systems require three specific ingredients and leadership capabilities, which are listed below. These informed three leadership logics required to lead in an increasingly complex world. The fourth, industrial revolution, needs a new leadership algorithm or logic: one in which leaders think and operate inter-systemically, leveraging the interdependencies between humans and machines:

1. Emergence: new patterns or ideas that emerge as a result of local interactions and intuitive insights. In organizations, these emergences need to be defined, shaped, and formed, and then brought forth into practical implementation and results. Here we explore a set of capabilities we refer to as ego leadership.

2. Openness, adaptability, and self-organization: organizations that are open to their environments with permeable boundaries and exchanges with the larger environment are essential to maintaining the health of the system. Also, the organizational system adapts to changes in the environment as well as changes from within in order to maintain some kind of equilibrium. Technological developments like social media, the internet of things, and blockchain are enabling selforganization at an alarming pace and call for a redefinition of the role of management and leadership. This implies a leadership capability of openness, allowing and encouraging mutual influence between departments, stakeholders, and systems, and an ability to leverage the interdependencies or exchanges within the organizational eco-system. We have referred to this logic and set of capabilities as eco leadership.

\footnotetext{
${ }^{9}$ https://www.hult.edu/en/executive-education/insights/ego-eco-and-intuitive-leadership/
} 
3. Holism: the whole of something is greater than the sum of its parts, and parts are interdependent and interactive through continuous mutual feedback processes. This implies a leadership capacity to take distance in order to see the bigger picture, sensing into the higher purpose, meanings, emerging patterns and interdependencies. This is not always a rational or cognitive process. Here we explore a set of capabilities referred to as intuitive leadership Within this framework of complexity, we set out to examine how these three leadership logics of ego, eco, and intuitive enable leaders to face the challenges of complex business environments. We first provide definitions from the literature and our experience, and then explore how these three individual leadership logics show up or manifest in practice.

In summary, we could describe ego, eco, and intuitive leadership as follows:

- Ego leadership is about working with and within boundaries, bringing form, focus and speed. Ego leaders are good at creating focus and setting goals. They tend to use linear, cause-and-effect thinking and are good at mobilizing resources at speed to achieve objectives. When the ego becomes stuck in its need for security, status, or recognition, it may appear excessively self-focused, narcissistic, or egocentric;

- Eco leadership is about working between boundaries, bringing emergence of new ideas through leveraging interdependencies, and generative dialogue. Eco leaders create the psychological safety for diverse stakeholders to engage through generative dialogue, a dialogue that creates the space for thinking together across organizational boundaries. Eco leadership might create high levels of uncertainty and chaos if not rooted in a very clear organizational purpose;

- Intuitive leadership is about working beyond boundaries, tuning into the possibilities of the unknown and connecting the dots. The intuitive approach is most useful when complemented by the ego or eco capability. Leaders describe intuition as an ability to see the unseen possibility.

We have chosen to use the following descriptors: Shaper to describe the ego leadership abilities; Integrator to describe the eco leadership abilities; and Connector to describe the intuitive leadership abilities. ${ }^{10}$ Some leaders are so strongly rooted in a style they become stuck within that style, unable to flex to meet the needs of changing contexts, thereby reducing their effectiveness.

Voice-of-clients and customer interviews don't really work unless they trust us. We tell our doctor, lawyer, or therapist everything they need to know so they can help us. But only if we trust them. The same is true for our colleagues or customers when we seek information to innovate for them. We build trust with our credibility, reliability, and a sincere interest in their needs and well-being.

Our profound interest and the purpose of business is to create and keep customers for sustainable Q in the most reliable way for the long term. For this we need to build our growth capabilities, because we need capabilities to get these results. Steven Covey said we need to balance P (production or results) with PC (productive capabilities). Let's add a time dimension - this year vs. future years - and ask, "Where do you spend most of your time?" The honest answer for many is this year's results. It can help to pursue near-term capabilities and long-term results. But the key to strong organic growth is building our capabilities for the future. Can we think of any champions in any endeavor that didn't first build their capabilities?

Building sustainable capabilities requires sectors and leading businesses to collaborate. Seen together, the transformations go to the heart of how interconnected all of the challenges

${ }^{10}$ Ibid. 
are. Transform our systems and achieve the Sustainable Development Goals: "11 "Time is running out, the world has to follow our example and move from words to measurable facts."

This emphasis on transforming entire systems of how we live and work is not an isolated point of view. Increasingly, leaders in sustainability, business, and government are advocating this approach. This will involve concentrating on the products and services that will make a difference to the achievement of the SDGs at the same time as identifying and addressing any areas where their products or operations are having a negative impact. It will be important for businesses consistently to drill down into the relevant targets and implement SDG policies and initiatives that can be effectively measured against those targets.

\section{THE MODEL FOR LEADING COMPLEX CHANGE AT SCALE ALIGNMENT}

We know what we know (facts), we know what we think (assumptions), and we know what we don't know (questions), but we don't know what we don't know (surprises). To know what truly matters, providing insights that were previously unimagined, this is how you avoid errors of omission and failing to uncover unarticulated needs.

These are not "cheap tricks to fool people into thinking that you're listening when you're not." These are tips to telegraph that we are listening diligently and truly interested, so the customer will continue providing insights.

Figure 1. Theory U

Theory U

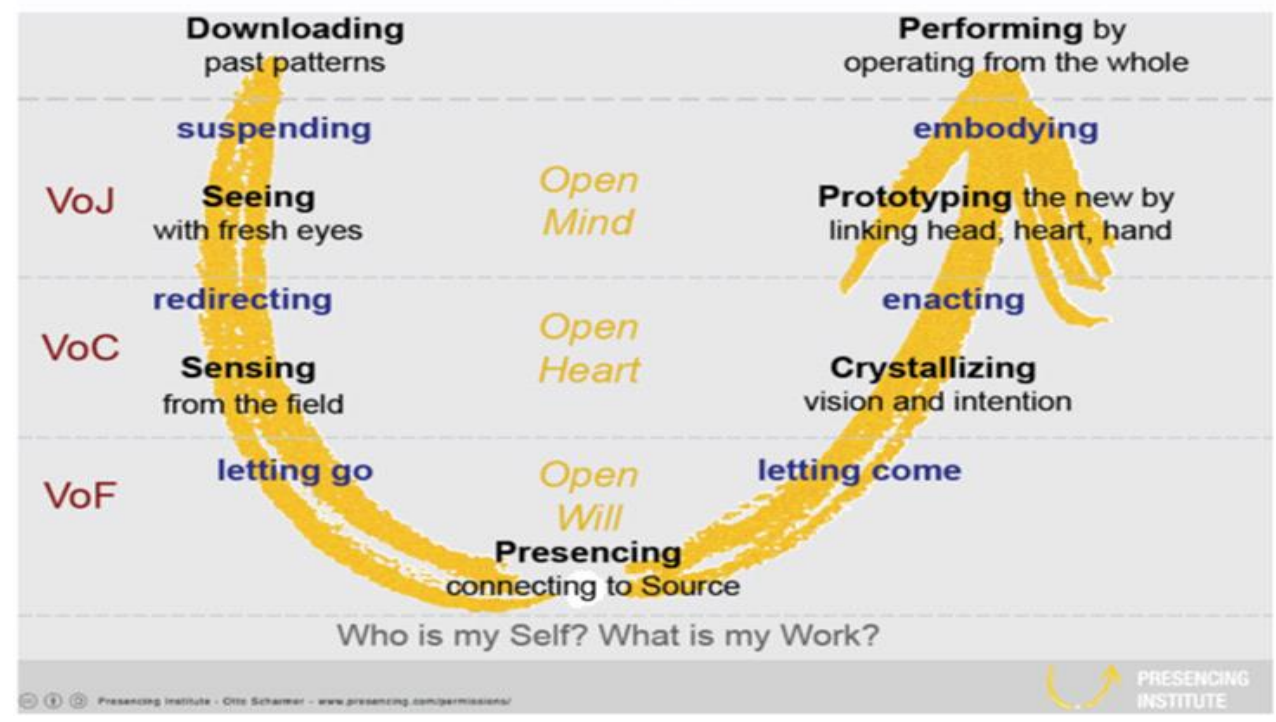

Source: https://www.hult.edu/en/executive-education/insights/ego-eco-and-intuitive-leadership/

In situations of disruptive change, the key capacity that is needed from individuals, teams, organizations, and society is to stop, really pay attention, let go of old definitions of identity, let new future possibilities come, and make a connection to one's higher self - defined as your strongest future possibility. The action learning community at MIT has explored what it takes to learn from the emerging future, illustrated and introduced as theory U (Fig. 1).

\footnotetext{
${ }^{11}$ https://www.leadershipandchangemagazine.com/interview-otto-scharmer/
} 
Through Theory U, and leading from the emerging future ${ }^{12,13}$ from ego-system to ecosystem economies, we look through the deeper lens of not only the "what" (results) or "how" (process) of change, but also the "who": the source of change. We focus not only on the microor meso-level, but also on the macro-and mundo-levels: our individual, relational, institutional. and global transformation.

Building awareness and focusing attention at different levels (self and others) and contexts has been summarized in Figure 2.

That is what our generation of change-makers are called to do. We are almost like a "middle generation." Before us was the generation that talked about macro and mundo changes but didn't put them into practice. Change for them was changing others. After us comes a generation that is very concerned with personal and relational change, and very capable, but less focused on institutional, macro-mundo change. All these wonderful initiatives of social entrepreneurship around the world almost never go to scale. So, how are they able to transform organizations and larger institutions?

Figure 2. Levels of awareness and focused attention

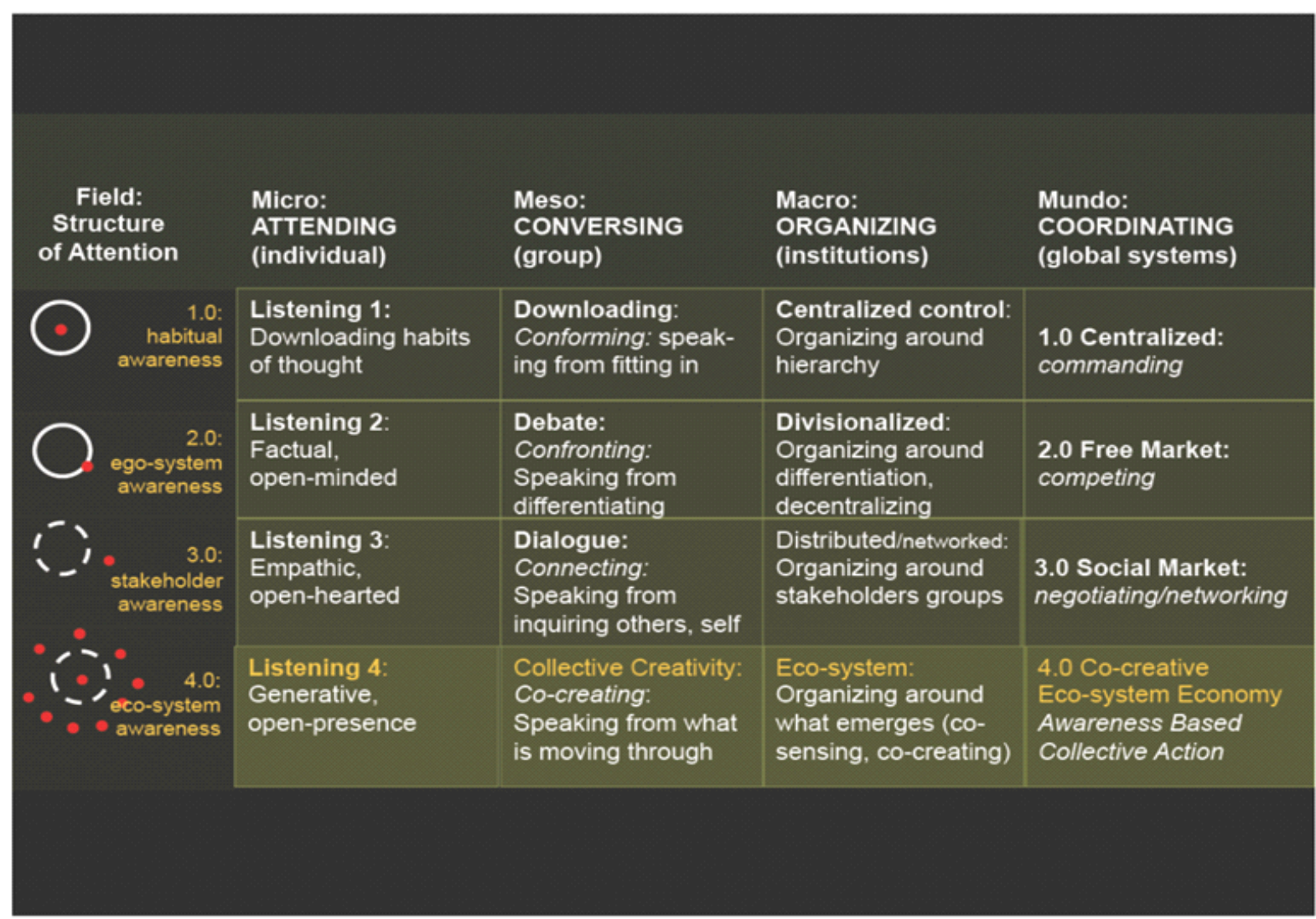

Source: https://www.sebokwiki.org/wiki/What_is_Systems_Thinking\%3F

As practitioners, we can lead change projects ourselves, and integrate many different frameworks and tools to deepen our insights to obtain better, more sustainable Q solutions. Theory $\mathrm{U}$ is a meta-framework that integrates with appreciative inquiry, open space, world cafe, systems thinking and other tools. That's important from a practitioner's point of view.

\footnotetext{
12 Ibid.

${ }^{13} \mathrm{https}: / /$ www.sebokwiki.org/wiki/What_is_Systems_Thinking\%3F
} 
A framework that helps to discern the developmental stages of banks, health care organizations, society and more. It provides a map-though every journey is different-of where we could go this twenty-first century.

As Scharmer emphasizes, the traditional approaches to change miss two dimensions. The first one is the source or the consciousness dimension, the deeper personal level of change. The second dimension missing is that of the larger societal transformation. The disruptive changes we face are bringing these two missing dimensions more and more into focus. Both dimensions are crucial for achieving new, sustainable Q.

We need to go back and forth between them. If we don't, we are missing essential information and also connection points with the next generation of employees and customers and stakeholders. If we QP don't connect, we are not in a position to perform our basic duties. With the Q of connections and QMS innovation we can act as a key leverage point to transform our organizations and society.

To be Q practitioners we need to learn and connect with others, start with our teams meeting regularly, organize a coaching circles and practice this using the work tasks and reflection questions and practices which helps to feed forward better solutions, change initiative that inspires your best energies and commitment.

It's important to keep in mind, however, that if we simply mimic nature without considering the broader ecosystem, we could still end up with innovations that aren't futureproof. One way to make our QMS improvements sustainable is to consider and apply TRIZ principles, or other design principles (DOE, QbD, QFD...).

\subsection{What are the problems that $\mathrm{QM} / \mathrm{QPs}$ are facing today?}

Organizations operate in difficult conditions today, where high competitiveness is required at increasing labor costs and rising prices of input materials. In many business sectors today, focus on quality as a competitive tool is being replaced by a focus on innovation. Research exploring connections between quality management, innovation, and company performance suggests that quality is 'necessary but insufficient' in business today. ${ }^{14}$

These organizations were adapting to new requirements by modifying existing management systems and introducing new models as lean production, customer focus and quality improvements. New models can have hidden contradictions in terms of ambiguous strategies and discourses. ${ }^{15,16}$ Harnesk ${ }^{17}$ points out three embedded contradictions:

- Collectivism versus individualism;

- Manipulation versus empowerment;

- Standardization versus innovative learning.

Some more work contradictions are reported by Shachter: ${ }^{18}$

- Quality and efficiency;

\footnotetext{
${ }^{14}$ Valeri Souchkov, The International TRIZ Association - MATRIZ, 2014.

https://matriz.org/wp-content/uploads/2016/11/TRIZ-Glossary.pdf

${ }^{15}$ Dara Schniederjans and Marc Schniederjans, ,Quality management and innovation: new insights on a structural contingency framework", Vol. 1, No. 2, 2015.

${ }^{16}$ Roland Harnesk and Lena Abrahamson, „TQM: an act of balance between contradictions“, The TQM Magazine Vol. 19 No. 6, 2007, pp. 531-540.

${ }^{17}$ Dara Schniederjans and Marc Schniederjans, ,Quality management and innovation: new insights on a structural contingency framework“, Vol. 1, No. 2, 2015.

${ }^{18}$ Harvey Schachter, „Don't ignore work contradictions - leverage them.“ https://www.theglobeandmail.com/report-on-business/careers/management/dont-ignore-work-contradictionsleverage-them/article37591681/
} 
- Quality and cost reduction;

- More for less;

- Clarity and alignment;

- Superb customer service and the need to keep staffing low.

QMS built according to ISO 9001 requirements are too often used as a tool for managing nonconformities and corrective actions in order to provide the solution for lowering defects and scrap rates. Contradictions are not considered in ISO 9001 and are therefore ignored. The question is, what are the effects of contradictions on running an organization? The proposed solution by Harnesk and Abrahamson ${ }^{19}$ is that organizations and leaders need to prioritize, balance, and navigate to keep the business running. However, the true solution is to eliminate contradictions entirely and thus eliminate the negative effects caused by contradictions. The tool to eliminate contradictions and to help organizations to innovate is the Theory of Inventive Problem Solving (TRIZ), which was developed by Genrich Altshuller in the mid-twentieth century in the Soviet Union.

Originally TRIZ was developed to solve technical problems. Ellen Domb ${ }^{20}$ stated that TRIZ is also an excellent problem-solving methodology for non-technical problems. TRIZ has been very helpful in many areas of politics, service development and delivery, organizational structure, social welfare systems, inter-personal relations, and resolving disputes.

\subsection{How the TQM Concept Should be Complemented by Combining Deming's Theory of Profound Knowledge with the Theory of Inventive Problem Solving (TRIZ)}

Today Quality practitioners are placing considerable emphasis on achieving compliance with QMS standards (i.e. ISO 9001, EN 15224, ISO/TS16949, etc.) which is essential to ensure compatibility in the supply chain. TRIZ is a tool to improve creativity which is needed to help solve difficult problems or predict the future development of systems. Most often it is helpful in situations that present a serious threat to the organization's survival. Predictions about the future form the bases upon which all decisions are made.

\footnotetext{
${ }^{19}$ Roland Harnesk and Lena Abrahamson, „TQM: an act of balance between contradictions“, The TQM Magazine Vol. 19 No. 6, 2007, pp. 531-540.

${ }^{20}$ Ellen Domb, ,TRIZ for Non-Technical Problem Solving““. https://triz-journal.com/triz-non-technical-problem-solving/
} 
Table 1. Merging Deming's Theory of Profound Knowledge with Altshuller's Theory of Inventive Problem Solving (TRIZ)

\begin{tabular}{|c|c|c|}
\hline \multicolumn{3}{|c|}{$\begin{array}{l}\text { Merging Deming's Theory of Profound Knowledge with Altshuller's Theory of Inventive Problem Solving } \\
\text { (TRIZ) }\end{array}$} \\
\hline Area & $\begin{array}{l}\text { Four elements of Theory of Profound } \\
\text { Knowledge }\end{array}$ & Basic elements of classical TRIZ \\
\hline System & Focus is on the system & $\begin{array}{l}\text { Problems are always solved by treating } \\
\text { the system as a whole. }\end{array}$ \\
\hline Variation & Recognition of variability & - \\
\hline Knowledge & Theory of knowledge & $\begin{array}{l}\text { Knowledge base for problem solving: } \\
40 \text { inventive and } 4 \text { separation principles } \\
76 \text { standard solutions } \\
17 \text { generic trends } \\
\text { Impact databases }\end{array}$ \\
\hline Psychology & Psychology & - \\
\hline $\begin{array}{l}\text { Creativity and } \\
\text { Innovation }\end{array}$ & & $\begin{array}{l}\text { Tools for improvements in creativity and } \\
\text { Inventive Problem-Solving Algorithm } \\
\text { (ARIZ) }\end{array}$ \\
\hline
\end{tabular}

Any improvement requires the prediction of evolution. To find the best solution the cooperation of interdisciplinary teams is required, which is why we decided to develop a tool based on merging Deming's System of Profound Knowledge with Altshuller's Theory of Inventive Problem-Solving. Such a tool will enable us to fulfill Feigenbaum's foundation for business success: Innovate in product and service leadership and cycle-time management. ${ }^{21}$

\subsection{Short description of TRIZ crossover QMS application}

The TRIZ Crossover QMS mobile application enables the application of TRIZ tools and techniques in the world of quality management. It was developed to improve the creativity of managers and Quality practitioners. Business and management innovation have always been among the most crucial drivers of success, but today innovation is essential for competitiveness in global markets. We strongly believe that creativity leads to the innovation required to improve our systems, processes, products, and services. Today TRIZ is recognized as one of best tools for problem-solving: especially ones that require innovative solutions for system evolution prediction and discovering new approaches with minimal consumption of resources. This application provides a selection of powerful solution techniques, while the Instructions for Use manual provides basic TRIZ fundamentals and analytical methods that creates a new mindset needed to enable the practitioner to improve Quality and other management systems.

To use TRIZ tools for improving your QMS, consider your organization as a system generating value. The concept of value can be used as a quality measurement indicator.

$$
\mathrm{Q} \text { indicator }=\text { Value for the customer } / \text { Cost for organization }
$$

In the modern management approach, the strategic focus is on the ratio of value and costs. The difference between value and costs creates a variety of strategic options for setting the competitive price.

\footnotetext{
${ }^{21}$ Armand V. Feigenbaum, The Future of Quality Management. http://www.qualitydigest.com/may $98 / \mathrm{html} /$ futureq.html
} 
To be competitive in the new global economy we have to invent products and services that are of high value to customers and are generated by cheaper processes and systems. TRIZ crossover QMS is a tool that can help quality practitioners think outside the box in order to find solutions best fitted to customers and organizational needs and be implemented by available resources.

TRIZ crossover QMS application is intended to be used by quality managers and practitioners and other process owners and experts participating in cross-functional teams for improvement.

The tool was designed to improve creative thinking for teams and individuals. It has the role of being a creative booster encouraging users to select inventive principles for solutions and implement the right method for their implementation.

How does it work? After installation and start of the application, the front page appears on the screen. Press the START button and the MENU screen will appear showing possible selections:

a) 40 inventive principles,

b) 4 separation principles,

c) 7-step problem-solving algorithm,

d) 8-step system evolution algorithm,

e) 4 sets of improvement inventive principles,

f) $39 \times 39$ contradiction matrix.

Follow the selected algorithm and use the inventive and separation principles to determine the solution you are looking for according to the instructions in various steps of the selected algorithm. Four sets of inventive principles are selected for fast-track improvement according to Fayer, ${ }^{22}$ who recommends four groups of problems where the inventive principles can be related to: substances, harmful factors, increase in effectiveness and ideality, and using scientific effects. The contradiction matrix, or Altshuller Matrix, suggests inventive principles to solve contradictions arising while trying to improve a feature of any product, process, or system.

\section{Sažetak:}

\section{INOVACIJA KVALITETE IMPERATIV JE ZA NOVU, ODRŽIVU KVALITETU (ŽIVOTA!)}

Ekološki kolaps i klimatska katastrofa prijete svemu. Društveni mediji sve izluđuju. Poduzimaju se divovski koraci za izgradnju ekološke svijesti i nove održive kvalitete života. U svojoj ulozi QM-QP-a (menadžeri i profesionalci u kvaliteti) odgovorni su za pružanje stručnosti u svim dimenzijama QMS-a (sustavi upravljanja kvalitetom), planiranja, osiguranja, kontrole i poboljšavanja. Poznavanje standarda, modela i drugih propisa, kao i alati i tehnike za mjerenja i poboljšanja očigledni su dijelovi usluga. Mnogo je razloga za angažiranje QP-a iz osnovne želje za usmjerenost na kvalitetu informiranjem o stvaranju novih kvalitetnih usluga ili omogućavanju poboljšanog pristupa kupcima novoj, održivoj kvaliteti. Postojeći QMS-ovi i njihove prakse i modeli u organizacijama više nisu učinkoviti za izazove, posebno vezane uz umrežene tvrtke i ekosustave. Postoji li profesionalna svijest o globalnom stanju kvalitete?

Ključne riječi: kvalitetna inovacija, sistemsko razmišljanje, osobna revitalizacija, održavanje promjena.

\footnotetext{
${ }^{22}$ Alternatives Vorgehen nach S. Fayer, https://de.wikipedia.org/wiki/TRIZ.
} 


\section{LITERATURE}

1. Alternatives Vorgehen nach S. Fayer, https://de.wikipedia.org/wiki/TRIZ.

2. Domb, Ellen, „TRIZ for Non-Technical Problem Solving.“ https://triz-journal.com/triz-non-technical-problem-solving/

3. Dörner, D., The logic of failure - Recognizing and avoiding error in complex situations, Perseus books, Cambridge, Massachusetts, 1996.

4. Feigenbaum, A. V., The Future of Quality Management, http://www.qualitydigest.com/may98/html/futureq.html

5. https://www.weforum.org/rep HYPERLINK "https://www.weforum.org/reports/how-toend-a-decade-of-lost-productivity-growth"o HYPERLINK "https://www.weforum.org/rep HYPERLINK "https://www.weforum.org/reports/how-to-end-a-decade-of-lostproductivity-growth"orts/how-to-end-a-decade-of-lost-productivity-growth"rts/how-toend-a-decade-of-lost-productivity-growth

6. http://www3.weforum.org/docs/WEF_Sustainability_Strategy_2021.p HYPERLINK "http://www3.weforum.org/docs/WEF_Sustainability_Strategy_2021.pdf"df

7. https://www.sebokwiki.org/wiki/What_is_Systems_Thinking\%3F

8. https://www.hult.edu/en/executive-education/insights/ego-eco-and-intuitive-leadership/

9. https://www.sebokwiki.org/wiki/What_is_Systems_Thinking\%3F

10. https://www.leadershipandchangemagazine.com/interview-otto-scharmer/

11. https://www.pwc.com/gx/en/sustainability/SDG/sdg-2019.pdfetc

12. Harnesk, R. and Lena Abrahamson, „TQM: an act of balance between contradictions“, The TQM Magazine, Vol. 19, No. 6, 2007.

13. Leavengood, S. and T. R. Anderson, „Tugrul U. Daim, Exploring linkage of Quality Management to Innovation.“

https://www.researchgate.net/publication/265341241_Exploring_linkage_of_quality_man agement_to_innovation

14. Ossimitz, G., The development of system thinking skills using system dynamics modelling tools, Klagenfurt, Universitat Klagenfurt, 1997.

15. Proceedings of the 3rd ICQEM Conference, Barcelona, Spain, 2018.

16. Schachter, H., „Don't ignore work contradictions - leverage them“. https://www. theglobeandmail.com/report-on-business/careers/management/dont-ignorework-contradictions-leverage-them/article37591681/

17. Schniederjans, Dara and M. Schniederjans, „Quality management and innovation: new insights on a structural contingency framework", Vol. 1, No. 2, 2015.

18. Souchkov, V., ,,The International TRIZ Association - MATRIZ, 2014“. https://matriz.org/wp-content/uploads/2016/11/TRIZ-Glossary.pdf

19. Stacey, R. D., Griffin, D. and Patricia Shaw, Complexity and Management: Fad or Radical Challenge to Systems Thinking? (Complexity and Emergence in Organizations), Routledge, London, 2000. 